\title{
MANAJEMEN KEUANGAN RUMAH TANGGA TAKMIR MASJID RUNGKUT JAYA ${ }^{1}$
}

\author{
Mas'amah \\ Departemen Ekonomi Syariah-Fakultas Ekonomi Dan Bisnis-Universitas Airlangga \\ Email: mas.amah-13@feb.unair.ac.id
}

\author{
Atina Shofawati \\ Departemen Ekonomi Syariah-Fakultas Ekonomi Dan Bisnis-Universitas Airlangga \\ Email: atina-o@feb.unair.ac.id
}

\begin{abstract}
:
The goal of this research is to understand how management financial implementation work into muslim Family, especially at Takmir Rungkut Jaya Mosque. The research used descriptive qualitative approach. Data collection was results by interview and documentation. Pattern matching technique was used to perform data analytic. This technique to find the general description of financial management family work into muslim then adjusted to the implementation of sakinah finance. The result based on interviews with two households of Takmir Rungkut Jaya Mosque is both informants in research has implemented components financial management to reach sakinah finance in the life daily. The financial management component are income management main intention to worship, meet family needs, maintain self-respect for not begging, and leniency of life, and hold the principle of halal in seeking sustenance and work, and focusing on the intention of the afterlife. Expenditure Management consists of three expenditure items, household needs posts, social posts, and mosque needs posts, as well as using savings as outposts for cash inflows and expenditures, as well as household emergency funds.
\end{abstract}

Keyword: sakinah finance, income management, expenditure management, household finance.

I.

\section{PENDAHULUAN}

Perkawinan merupakan faktor yang penting dan agung dalam Islam. Perkawinan bukan sekedar amalan manusia yang bersifat duniawi, namun merupakan langkah menuju perbaikan individu dan masyarakat. Penghargaan Islam terhadap ikatan perkawinan sangat besar, sehingga ikatan perkawinan tersebut ditetapkan sebanding dengan melengkapi separuh dari agamanya.

Menurut Abdulloh (2007:5) rumah tangga muslim hendaknya mau menerapkan pilar-pilar syariat Islam agar terciptanya rumah tangga yang berpegang teguh pada kebenaran, keadilan, persamaan, memerangi kezholiman dari orang-orang yang Ialim, mencintai ilmu dan amal, tekun dalam mencari ilmu dan beramal dengannya, berbuat sebaik-baiknya, serta dapat menyelamatkan generasi Islam agar tidak tenggelam dalam budaya mengekor kepada Barat.

Penerapan pilar-pilar syariat Islam juga penting diterapkan dalam keuangan rumah tangga muslim yang tercermin pada pembentukan keluarga sakinah, dimana muslim menginginkan kehidupan rumah tangga yang tenang terutama

\footnotetext{
${ }^{1}$ Jurnal ini merupakan bagian dari skripsi Mas'amah, NIM: 041311433127, yang diuji pada tanggal 19 Juli 2018.
} 
dalam hal kevangan. Tamanni dan Mukhlisin (2013:8) mengemukakan bahwa sakinah dimulai dari keyakinan akan vang yang disimpan adalah vang yang halal, sehingga vang tersebut dapat digunakan sebagai alat transaksi pembayaran serta dapat dibelanjakan. Halal merupakan fondasi dari sebuah ketenangan dalam keuangan rumah tangga.

Gozali dalam Tamanni dan Mukhlisin (2013:9) mengartikan bahwa "sakinah finance" telah terwujud jika seseorang mampu "menempatkan harta di tangannya, tetapi tidak di hatinya", dalam artian ketika seseorang tersebut dalam hatinya sudah muncul sifat qana'ah, dimana qana'ah itu sendiri merupakan keadaan seseorang yang tidak lagi merasa kekurangan ketika hartanya sedikit dan tidak pula boros ketika hartanya berlebih.

Sulastiningsih (2008:6) menyatakan bahwa dalam manajemen keuangan rumah tangga diperlukan pemahaman yang benar akan konsep dasar dalam berikhtiar dan berkonsumsi. Harta yang merupakan amanah dari Allah SWT tidak disalahgunakan penggunaannya, tetapi digunakan sebagai sarana untuk mencapai keberkahan dan keridhaan, serta untuk meningkatkan ketakwaan kepada Allah SWT.

Sakinah finance merupakan manajemen keuangan rumah tangga yang sejalan dengan prinsip-prinsip syariat Islam. Sakinah finance terbagi menjadi lima komponen pengelolaan, yaitu manajemen pendapatan, manajemen pengeluaran, manajemen impian dan keinginan, manajemen surplus dan defisit, serta manajemen ketidakpastian. Lima komponen sakinah finance berada dalam koridor maqashid syariah (tujuan dasar ditetapkannya suatu aturan agama dalam Islam). Maqashid syariah terdiri dari agama, jiwa, akal, keturunan, dan harta.

Sakinah finance bukan merupakan satu-satunya atau syarat yang paling utama dalam mencapai keluarga sakinah, namun setidaknya peranan stabilnya kondisi keuangan dalam rumah tangga semakin penting dalam kehidupan masa kini, dilihat dari semakin gencarnya gempuran konsumerisme maupun budaya hedonisme yang menghampiri setiap rumah tangga di Indonesia (Tamanni dan Mukhlisin, 2013:xiv).

Surabaya memiliki potensi keagamaan yang cukup besar. Berdasarkan data dari Dinas Kependudukan dan Pencatatan Sipil Kota Surabaya, pada tahun 2017 ditemukan data jumlah penduduk Surabaya sebesar 3.074.490 penduduk, dengan keragaman pemeluk agama: Islam 2.619.036 penduduk, Kristen 278.786 penduduk, Katholik 122.152 penduduk, Hindu 8.430 penduduk, Budha 45.341 penduduk, Konghucu 560 penduduk, dan kepercayaan lainnya 185 penduduk (http://Dispendukcapil.Surabaya.go.id).

Islam sebagai potensi keagamaan terbesar di Surabaya juga memiliki banyak 
Masjid yang tersebar di wilayah Surabaya. Berdasarkan data yang diperoleh dari Departemen Kementerian Agama terdapat 3.629 tempat ibadah, yaitu terdiri dari 1.714 Masjid dan 1.915 Mushalla yang tersebar di seluruh wilayah Surabaya pada tahun 2017 (http://simas.kemenag.go.id).

Masjid Rungkut Jaya merupakan salah satu Masjid yang ada di Surabaya. Masjid ini tepat berada di Jalan Wonorungkut Utara 7 No. 2, Kelurahan Wonorejo, Rungkut, Kota Surabaya, Jawa Timur. Masjid ini sudah berdiri selama 32 tahun, yaitu mulai dari peresmian Masjid pada tanggal 27 April 1986.

Sejak adanya Masjid Rungkut Jaya aktivitas keagamaan semakin meningkat, hal ini terlihat dari Masjid yang dijadikan sebagai pusat ibadah dan tempat melakukan segala aktivitas keagamaan. Masjid dijadikan sebagai tempat bermain atau belajar anak-anak, yaitu sebagai sarana untuk membina mental serta menjadikan hati condong dan terikat dengan Masjid sejak dini, dan dengan adanya Masjid semakin gencarnya silaturahim yang dijalin antar individu, rumah tangga, dan Masjid. Para kaum wanita pun mulai menggunakan jilbab.

Masjid Rungkut Jaya membawa perubahan dari sisi ekonomi. Masyarakat semakin mengenal ekonomi syariah, sejak adanya sarana Masjid tentang konsultasi ekonomi syariah untuk masyarakat umum. Masjid juga menjadi unit pengumpul zakat yang dikumpulkan dan disalurkan setiap bulan. Penerima zakat tersebut ialah orang yang tidak bisa membayar hutang, vang sekolah, dan apapun hal serupa semuanya dibiayai oleh Masjid.

Masjid Rungkut Jaya menyediakan penginapan bagi ibnu sabil. Penginapan tersebut sering dihuni oleh mahasiswa, tahun 2017 terdapat dua mahasiswa dari STAIL (Sekolah Tinggi IImu Agama Lukman Al Hakim) Hidayatullah dan Ma'had Umar Bin Khattab di Tenggilis. Kedua mahasiswa tidak membayar apapun selama menginap dan bahkan mendapatkan vang setiap bulan dari Masjid untuk kebutuhan hidup dan biaya pendidikan.

Peran Masjid tidak terlepas dari peran para Takmir Masjidnya. Tahun 2017, terdiri dari tiga belas Takmir dengan wawasan ilmu agama yang luas. Semua Takmir Masjid Rungkut Jaya telah menunaikan ibadah haji, dan mayoritas merupakan orang-orang yang berperan besar terhadap sejarah dan perkembangan Masjid Rungkut Jaya, bahkan ketua Takmir Masjid dari awal kepengurusan sampai kepengurusan tahun 2017 tetap diketuai oleh Bapak Suherman Rosyidi.

Takmir Masjid Rungkut Jaya menempatkan pengeluaran keuangan rumah tangganya ke dalam tiga pos pengeluaran, yaitu pos kebutuhan keluarga, pos untuk sosial, dan pos untuk Masjid. Pendapatan diperoleh dari profesi utama masing-masing Takmir, karena Takmir dan kegiatan dakwah yang digeluti bersifat non materi. 
Rumusan masalah pada penelitian ini adalah apakah ada kesesuaian penerapan sakinah finance pada manajemen keuangan rumah tangga Takmir Masjid Rungkut Jaya? .

Adapun tujuan dari penelitian ini adalah untuk mengetahui kesesuaian penerapan sakinah finance pada manajemen keuangan rumah tangga Takmir Masjid Rungkut Jaya.

\section{LANDASAN TEORI}

Rumah tangga (terdiri dari suami, istri, dan anak-anak) merupakan komunitas terbaik dan efektif untuk mewujudkan harmonisasi kehidupan dunia dan akhirat. Harapan setiap keluarga Muslim adalah terwujudnya rumah tangga yang sakinah, damai, tenteram, sejahtera, serta tercukupinya sandang maupun papan(Sulastiningsih, 2008:6).

Setiap rumah tangga dalam pengalokasian dana atau pemakaian vang dalam praktek kehidupan sehari-hari mempunyai seni pengelolaan tersendiri, hal ini dipengaruhi oleh kebiasaan, pengalaman, serta pengetahuan. Menurut Manullang (1981:4-8) dalam melaksanakan rencana pengeluaran yang telah disusun dapat dilakukan dengan berbagai model/sistem, yaitu sistem amplop, sistem buku kas, sistem kas kelvarga, sistem kas harian.

Senduk (2000:35) menyatakan bahwa setiap rumah tangga mempunyai cara yang berbeda dalam mengelola keuangannya. Suami menyetorkan semua penghasilan kepada istrinya lalu sang istri yang mengelola vang tersebut, ada yang suami istri sama-sama bekerja dan menyimpan penghasilannya masingmasing dan pengelolaan keuangan menggunakan penghasilan suami atau masing-masing pihak sama-sama menanggung pengelolaan keuangan tersebut sebanyak $50 \%$.

Sakinah adalah kondisi ketenangan yang menjadi ciri utama dari sebuah kehidupan keluarga. Sakinah dimulai dari keyakinan bahwa semua yang ada di dalam dompet adalah halal, baik dari cara perolehan maupun penempatannya, sehingga menjadi fondasi dari sebuah ketenangan dalam kehidupan keluarga karena semuanya telah sesuai dengan prinsip Islam apabila digunakan untuk suatu keperluan (Tamanni dan Mukhlisin, 2013:5-8).

Menurut Wibawa

(2003:32)

Manusia dikatakan sukses dan sudah mencapai kebahagiaan apabila vang tidak lagi mengendalikan kehidupan seseorang tetapi oranglah yang mengendalikan vang, dimana vang dipandang sebagai sarana untuk mencapai tujuan yang hakiki (Wibawa, 2003:32).

Niat merupakan langkah yang paling utama dalam bekerja. Seorang muslim dalam melakukan aktivitas atau kegiatan harus diniatkan untuk beribadah dan mencari ridha Allah dan tidak berorientasi pada kehidupan duniawi. 
Sifat qana'ah dan lapang dada perlu dimulai dengan menumbuhkan kesadaran adanya campur tangan llahi dalam hidup, karena hal itu merupakan aset ketentraman hidup (sakinah) yang tidak ada bandingannya (Tamanni dan Mukhlisin, 2013:14). Hal ini sesuai dengan firman Allah SWT dalam surat AdzDzariyaat ayat 56:

Artinya: "Dan aku tidak menciptakan jin dan manusia melainkan supaya mereka mengabdi kepada-Ku." (Adz-Dzariyaat:56)

Pada ayat Adz-Dzariyaat ayat 56 di atas berdasarkan tafsir Quthb (2004:49) bahwa manusia dalam mengerjakan sesuatu harus diniatkan untuk ibadah pada Allah SWT, sebab Allah SWT adalah pemilik mutlak harta sedangkan manusia sebagai pemegang amanah.

Halal merupakan rambu utama dalam mencari keuangan sakinah. Halal merupakan syarat mutlak bagi terwujudnya keberkahan harta, yaitu cara memperolehnya dengan jalan yang dibenarkan oleh Allah SWT (Tamanni dan Mukhlisin, 2013:15). Syafi'i Antonio (2011:95) menyatakan bahwa halal atau haramnya suatu rezeki atau harta ditentukan oleh beberapa hal, yaitu sumber harta, cara perolehannya, cara pengelolaannya, dan cara membelanjakannya.

Antonio (2011:97) menyatakan bahwa keutamaan bekerja dalam Islam adalah memiliki nilai pahala, karena bekerja merupakan kewajiban dalam Islam dan bekerja termasuk ibadah. Sesuai dengan Al-Qur'an surat Al-Jumu'ah ayat 10 berikut:

Artinya: "Apabila telah ditunaikan shalat, Maka bertebaranlah kamu di muka bumi; dan carilah karunia Allah dan ingatlah Allah banyak-banyak supaya kamu beruntung." (QS. Al-Jumu'ah:10).

Pada surat Al-Jumu'ah ayat 10 di atas dapat disimpulkan bahwa manusia dalam mencari rezeki (bekerja) harus tetap dalam koridor mencari ridha Allah SWT, agar mendapatkan keberkahan dan bernilai ibadah di dalamnya (Departemen Agama Rl, 2001).

Di antara jalan paling baik dalam meraih ketenangan dan keberkahan dari Allah SWT adalah dengan bekerja keras dan memulai setiap aktivitas di pagi hari. Kebiasaan bangun pagi bisa menanamkan semangat hidup sehat dan memicu produktivitas serta menyingkirkan sifat malas sejauh-jauhnya, langkah sederhana ini dapat membuat langkah menuju keuangan sakinah sebagai proses yang mudah (Tamanni dan Mukhlisin, 2013:16).

Dari sahabat Shokr Al Ghomidiy, Nabi Muhammad SAW bersabda:

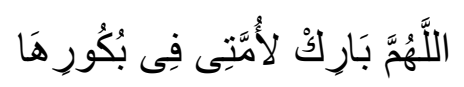

Allahumma barik li'ummati fi bukuriha

Artinya: "Ya Allah, berkahilah umatku di waktu paginya." (HR. Abu Daud no. 2606. Hadist ini dishohihkan oleh Syaikh Al Albani dalam Shohih wa Dho'if Sunan Abi Daud).

Dari Hadist di atas dapat disimpulkan bahwa di antara jalan paling baik untuk meraih ketenangan dan 
Mas'amah, et al/Jurnal Ekonomi Syariah Teori dan Terapan Vol. 6 No. 6 Juni 2019: 1114-1128; MANAJEMEN KEUANGAN RUMAH TANGGA TAKMIR MASJID RUNGKUT JAYA

keberkahan dari Allah SWT adalah dengan bekerja keras dan memulai setiap aktivitas saat hari masih pagi, kebiasaan bangun pagi dapat menanamkan semangat hidup sehat dan memicu produktivitas serta menyingkirkan sifat malas. Langkah ini akan menuju kevangan sakinah sebagai proses yang mudah (Tamanni dan Mukhlisin, 2013:16).

Silaturahim merupakan salah satu amal shaleh yang mendatangkan keberkahan bagi siapa saja yang menjalinnya, baik yang ada hubungan garis keturunan maupun tidak. Silaturahim dapat melapangkan rezeki, memanjangkan umur, memperbanyak keturunan, serta juga mendapat pahala di dunia dan di akhirat (Tamanni dan Mukhlisin, 2013:46-48).

Setiap suami mukmin wajib untuk memenuhi kewajiban dalam memberikan nafkah keluarga. Fungsi istri di dalam rumah tangga adalah sebagai manajer rumah tangga, yaitu mengelola rumah tangga, menjaga kehormatan dan harga diri suami maupun dirinya, serta mengelola harta suami (Sulastiningsih, 2008:19). Kelvarga sakinah tidak dibangun atas dasar prasangka, tetapi atas unsur kepercayaan di antara suami dan istri (Sulastiningsih, 2008:19).

Prioritas dalam keuangan sakinah terdiri dari:

1. Kewajiban membayar hutang

2. Menyalurkan ZISWAF (Zakat, Infak, Sedekah, dan Wakaf)

3. Kebutuhan pokok keluarga

\section{Dana darurat}

Setiap harta yang dimiliki manusia terdapat hak-hak kaum lemah, seperti fakir, miskin, orang tua, atau anak yatim. Harta tersebut disalurkan melalui ZISWAF (zakat, infak, sedekah, dan wakaf) yang mekanisme penyalurannya telah diatur dalam Islam. ZISWAF merupakan amal yang dapat menimbulkan keberkahan dalam harta pendapatan (Tamanni dan Mukhlisin, 2013:17-18)

Pemenuhan kebutuhan pokok merupakan tujuan yang harus ada dan mendasar bagi terciptanya kesejahteraan di dunia dan akherat, yaitu jiwa, agama, akal, keturunan, dan harta. Apabila tujuan dharuriyyat diabaikan, maka tidak akan ada kedamaian, yang timbul adalah kerusakan di dunia dan kerugian yang nyata di akherat (Syaparuddin, 2014:369).

Dana darurat adalah dana yang digunakan untuk berjaga-jaga dalam keadaan yang tidak terduga pada kebutuhan keluarga. Menurut Sulastiningsih (2008:105) terdapat tiga motif dalam manajemen kas, yaitu motif transaksi untuk menjalankan semua aktivitas, motif berjaga-jaga untuk memenuhi kebutuhan kas yang sifatnya mendadak dan tak terduga, dan motif spekulasi untuk diinvestasikan agar memperoleh keuntungan. Motif berjagajaga dapat berupa tabungan, baik tabungan umum atau tabungan khusus yang digunakan untuk menyimpan dana dan apabila terdapat pengeluaran yang sifatnya mendadak dan terduga. 
Wasiat dan waris merupakan komponen pengeluaran sekali seumur hidup yang harus dipersiapkan jauh-jauh hari. Wasiat tidak hanya sekedar distribusi harta warisan tetapi dapat ditujukan untuk hal-hal yang bersifat harapan kebajikan atau keinginan tertentu. Tata cara pembagian harta dari orang tua atau siapa saja anggota kelvarga yang telah meninggal dunia, lazimnya ada tiga cara harta tersebut dapat didistribusikan, yaitu wasiat, hibah, dan waris (Tamanni dan Mukhlisin, 2013:77-81).

Sulastiningsih 2008:48, rezeki bagi seorang mukmin merupakan ujian, dalam keadaan lapang atau dalam keadaan sempit, setiap mukmin harus menyadari bahwa semua itu merupakan salah satu bentuk ujian yang harus dihadapinya dengan penuh kesabaran dan kesyukuran. Menggunakan harta pada pertengahan, yaitu tidak boros dan tidak pelit, seperti yang tercantum dalam Q.S Al-Furqon ayat 67:

Artinya: "dan orang-orang yang apabila membelanjakan (harta), mereka tidak berlebihan, dan tidak (pula) kikir, dan adalah (pembelanjaan itu) di tengahtengah antara yang demikian." (Q.S AlFurqon:67)

Pada surat Al-Furqon ayat 67 di atas dapat disimpulkan bahwa seorang mukmin dalam membelanjakan harta tidak boleh berlebihan dan menimbulkan keburukan, tetapi mempertahankan keseimbangan antara sikap kikir dan sikap boros (Sulastiningsih, 2008:46).
Menurut Tamanni dan Mukhlisin (2013:103-116) cara mengelola surplus adalah dengan menabung atau investasi. Cara mengurangi defisit yaitu dengan meningkatkan pendapatan (mencari pekerjaan tambahan/sampingan atau bisa juga dengan menjual aset yang kurang diperlukan dan tidak terpakai), mengurangi jumlah pengeluaran non rutin (di luar kebutuhan pokok) dan pengeluaran yang tidak perlu seperti kebutuhan sekunder dan tersier, atau meminjam dana pihak lain (berhutang).

\section{METODE PENELITIAN}

\section{Pendekatan Penelitian}

Penelitian ini menggunakan pendekatan kualitatif, karena jawaban pada rumusan masalah penelitian ini tidak dapat diperoleh dengan cara menggunakan prosedur-prosedur statistik.

Penelitian ini menggunakan pendekatan kualitatif karena pertimbangan bahwa perlu adanya pendekatan secara langsung antara peneliti dan informan, sehingga dapat mengungkap secara lengkap dan memahami fenomena kesesuaian penerapan manajemen keuangan rumah menurut sakinah finance pada rumah tangga Takmir Masjid Rungkut Jaya.

\section{Ruang Lingkup Penelitian}

Batasan ruang lingkup penelitian ini berdasarkan rumusan masalah yang akan diteliti yaitu apakah ada kesesuaian penerapan sakinah finance pada manajemen keuangan rumah tangga Takmir Masjid Rungkut Jaya. Penelitian ini 
akan menjelaskan tentang praktik manajemen keuangan rumah tangga menurut sakinah finance dan membandingkan dengan realisasi yang ada di lapangan. Peneliti akan menjelaskan tentang sudah atau belum sepenuhnya dijalan penerapan manajemen keuangan rumah tangga menurut sakinah finance pada rumah tangga Takmir Masjid Rungkut Jaya.

\section{Jenis dan Sumber Data}

Data primer dalam penelitian ini berasal dari informan. Informan dalam penelitian ini adalah Takmir Masjid Rungkut Jaya, yaitu Ketua Takmir Masjid Rungkut Jaya, Sie Pendidikan, dan Sie Kewanitaan. Penelitian ini terfokus pada dua rumah tangga, karena pasangan suami dan istri yang sama-sama menjadi Takmir Masjid Rungkut Jaya terdiri dari dua rumah tangga saja.

Data sekunder merupakan data yang mendukung penelitian, yang didapatkan secara tidak langsung dari suatu objek penelitian. Data sekunder dalam penelitian ini di peroleh dari buku, jurnal, literatur, internet, dan sumber lain yang memiliki keterkaitan dengan penelitian ini.

\section{Unit Analisis}

penelitian ini, unit analisis pada rumah tangga Takmir Masjid Rungkut Jaya, dengan kasus kesesuaian sakinah finance pada penerapan manajemen keuangan rumah tangga.

Pemilihan unit analisis tersebut dikarenakan peneliti ingin meneliti lebih dalam mengenai pelaksanaan manajemen keuangan rumah tangga yang termasuk didalamnya adalah manajemen pendapatan dan manajemen pengeluaran yang sesuai dengan komponen sakinah finance. Manajemen pendapatan yang dianalisis terkait pada niat dalam mencari rezeki, prinsip halal, memulai pekerjaan di pagi hari, menjalin silaturahim, dan pembagian peran dalam rumah tangga. Manajemen pengelvaran yang dianalisis terkait pada penentuan prioritas, dan penanaman sifat qana'ah dalam mendapatkan rezeki.

\section{Pengumpulan Data}

1. Wawancara

Peneliti menggunakan teknik wawancara dengan tipe open ended untuk mempermudah dalam proses penelitian dengan mendapatkan hasil yang akurat dan dapat dipertanggungjawabkan. Wawancara dilakukan secara langsung mengajukan pertanyaan kepada rumah tangga takmir Masjid Rungkut Jaya yang menjadi informan.

2. Dokumentasi

Dokumentasi dalam penelitian ini adalah bukti berupa foto bersama antara peneliti dengan informan ketika sedang melakukan wawancara, dan hasil rekaman wawancara yang ditulis ulang dalam bentuk tulisan (transkip percakapan antara informan dengan peneliti).

\section{Teknik Keabsahan Data}


Trianggulasi yang digunakan dalam penelitian ini adalah trianggulasi sumber dan trianggulasi teori. Dalam penelitian ini trianggulasi sumber dilakukan dengan jalan membandingkan hasil wawancara antara informan, yaitu membandingkan hasil wawancara antara suami dan istri pada masing-masing rumah tangga guna memperoleh keterkaitan antar data sehingga menghasilkan data yang akurat.

Dalam penelitian ini trianggulasi teori dilakukan dengan cara membandingkan hasil wawancara dengan teori sakinah finance guna memperoleh kesesuaian dan keterkaitan antara data dan teori.

\section{Teknik Analisis Data}

Dalam penelitian ini, peneliti menggunakan teknik analisis penjodohan pola. Penjodohan pola bertujuan untuk membandingkan hasil temuan dari penerapan manajemen keuangan rumah tangga Takmir Masjid Rungkut Jaya dengan teori sakinah finance.

\section{HASIL DAN PEMBAHASAN}

\section{Gambaran Umum Subjek Penelitian}

Rumah tangga pertama (Bapak Suherman Rosyidi dan Ibu Ummi Kaltsum) telah menikah selama 41 tahun, dan memiliki tiga anak (anak pertama meninggal) dan dua cucu.

Bapak Suherman Rosyidi bekerja sebagai dosen ekonomi Islam di UNAIR (Universitas Airlangga), menjadi DPS (Dewan Pengawas Syariah) di BMT ABADA (Baitul Maal wat Tamwil Airlangga Bakti
Persada), BPRS (Bank Perkreditan Rakyat Syariah) Amanah Sejahtera Gresik, BPRS Unawi Barokah Sidoarjo, komisaris di BPRS Lantabur Jombang. Beberapa kegiatan rutin yang dilakukan, yaitu tabligh, mengisi siaran Radio Suara Muslim Surabaya, takmir, konsultan ekonomi syariah di Masjid Rungkut Jaya, dan kegiatan lainnya.

Ibu Ummi Kaltsum sebagai ibu rumah tangga dan memiliki kegiatan rutin seperti menjadi bendahara di Pengawas (Pengajian Wanita Surabaya) pada bidang pengurus pendidikan formal, belajar dan mengaji di Masjid, serta kegiatan lainnya.

Penghasilan rumah tangga ini sebulan kurang lebih sebesar Rp. 13.000.000,- yang berasal dari semua akumulasi pendapatan. Pendapatan tetap dan rutin keluarga ini sekitar Rp. 4.000.000,- perbulan.

Rumah tangga kedua (Bapak Ahmad Sugeng dan Ibu Retno Sunarsih) telah menikah kurang lebih selama 36 tahun, dan memiliki dua anak (anak kedua meninggal) dan tiga cucu.

Bapak Ahmad Sugeng bekerja sebagai dosen MTQ (Musabaqah Tilawatil Qur'an) atau Tarbiyah di jurusan Manajemen Pendidikan STAIL (Sekolah Tinggi IImu Agama Lukman Al Hakim) pada tahun 1999-sekarang. Lima kali pindah di Depnaker (Departemen Tenaga Kerja) dan sekarang pensiunan Depnaker mulai tahun 2011 . Beberapa kegiatan rutin yang dilakukan, yaitu mengajar tarjim (terjemahan) dan iqra' (membaca) 
dalam Al-Qur'an di Masjid Rungkut Jaya, mengajar ngaji untuk para lansia di Masjid Rungkut Jaya, belajar ngaji di pondok, menjadi sie pendidikan di Masjid Rungkut Jaya, serta kegiatan rutin.

Ibu Retno Sunarsih sebagai ibu rumah tangga dan pensiunan, kegiatan rutin yang dilakukan ialah belajar dan mengaji bersama ibu-ibu, belajar tahsin (menyempurnakan bacaan) hadits di Masjid Rungkut Jaya, menjadi sie wanita di Masjid Rungkut Jaya, mengikuti PKK, dan kegiatan rutin lainnya.

Penghasilan rumah tangga ini sebulan kurang lebih sebesar Rp. 5.000.000,- s/d Rp. 10.000.000,- yang berasal dari semua akumulasi pendapatan.

\section{Deskripsi Hasil Penelitian}

\section{Rumah Tangga Pertama}

Niat dalam bekerja agar kuat beribadah, menjaga kehormatan diri agar tidak mengemis, dan juga kelonggaran hidup. Memegang prinsip rezeki didapat secara jujur, bukan dari rezeki yang haram, dan membawa keberkahan. Bekerja di sektor halal dengan beberapa kegiatan dakwah lainnya.

Mengawali aktivitas di pagi hari dengan shalat berjamaah di Masjid. Kebiasaan rutin yaitu tadarusan bersama sekelvarga (baik anak dan cucu) selepas sholat subuh dan sebelum memulai aktivitas lainnya.

Metode silaturahim yang diterapkan adalah mendatangi langsung kediaman Ibu Bapak Suherman Rosyidi rutin seminggu sekali, sedangkan kerabat dan saudara mendatangi kediaman informan, karena Bapak Suherman Rosyidi selaku kakak tertua dari enam bersaudara. Silaturahim dengan tetangga dan warga sekitar dilakukan rutin setiap hari sebanyak lima kali sehari di Masjid dan via wa (whatsapp). Silaturahim berpengaruh terhadap pendapatan rumah tangga pertama, yaitu dengan semakin banyak link yang dimiliki maka membuka peluang untuk mendapatkan rezeki.

Bapak Suherman Rosyidi mengatur urusan eksternal (pencari nafkah) dan lbu Ummi Kaltsum mengatur urusan internal rumah tangga (menteri dalam negeri dan menteri keuangan). Pemegang kendali kevangan rumah tangga adalah Ibu Ummi Kaltsum, akan tetapi diterapkan unsur keterbukaan dan unsur kepercayaan antar suami istri agar saling mengetahui kesulitan dan kesenangan yang dialami. Ibu Ummi Kaltsum dalam mengatur keuangan menggunakan sistem amplop dan sistem rekening (tabungan).

Rumah tangga pertama tidak mempunyai hutang dan menempatkan zakat sebagai prioritas utama. Penyaluran zakat melalui Masjid dengan jumlah yang telah ditentukan sesuai aturan agama. Menurut Bapak Suherman Rosyidi sedekah terbagi menjadi dua yaitu harta dan bukan harta, yang termasuk harta adalah zakat dan infak. Infak dikeluarkan kapan saja dengan jumlah yang bervariasi karena tidak ada ketentuan di dalamnya. 
Penyaluran zakat, infak, dan sedekah lebih diutamakan pada saudara terdekat yang kurang mampu. Informan masih merancang wakaf, sebab wakaf merupakan amal jariyah yang dapat menolongnya kelak di akhirat. Sebagai takmir, informan tidak mengambil haknya sebagai amil sebab masih ada orang lain yang lebih membutuhkan.

$$
\text { Rumah tangga pertama }
$$

memenuhi kebutuhan sehari-hari di pasar tradisional karena lebih segar dan harga lebih murah, sedangkan kebutuhan bersifat bulanan berbelanja di supermarket. Menggunakan satu tabungan untuk segala kebutuhan rumah tangga atau bersifat universal, kecuali dana pensiun karena sudah terpotong otomatis pada gaji.

Informan telah merancang wasiat dan warisan dalam bentuk tertulis, dimana warisan cara pembagiannya sesuai dengan undang-undang agama, yaitu istri mendapat $1 / 6$ dan sisanya dibagi pada anak dimana anak laki-laki mendapatkan $2 x$ lipat dari anak perempuan.

Cara rumah tangga pertama berqana'ah adalah kepemilikan tidak dilihat dari berapa banyaknya, tetapi dilihat dari berapa banyak manfaatnya. Menerima segala rezeki yang diterima dengan cara bersyukur, baik banyak maupun sedikit.

Menghadapi surplus dan defisit, rumah tangga pertama mengusahakan selalu ada sisa saldo dalam pengelolaan keuangan, apabila tidak dapat terhindar dari defisit maka mengambil dari dana darurat atau mengambil dari uang yang sudah diamplop-amplopkan untuk segala kebutuhan keuangan rumah tangga.

\section{Rumah Tangga Kedua}

Niat utama untuk mengurusi kelvarga merupakan kewajiban dalam agama dan tanggung jawab sebagai kepala rumah tangga. Memegang prinsip halalan thoyyiban serta semua rezeki yang didapat sudah diatur oleh Allah, dimana halalan thoyyiban yaitu rezeki yang didapat sesuai koridor Islam dengan adanya keselarasan antara fisik dan ilmu yang dimiliki dengan pekerjaan yang dilakukan. Bekerja di sektor halal dengan kegiatan dakwah lainnya.

Memulai aktivitas di pagi hari agar semua kegiatan dapat diselesaikan. Kebiasaan berdzikir setelah sholat subuh sampai memasuki waktu sholat dhuha.

Silaturahim dilakukan dimana saja, baik dalam kehidupan sehari-hari, yaitu bertemu dengan muslim lainnya di Masjid termasuk juga dengan tetangga, silaturahim dengan keluarga dan kerabat dekat tidak rutin sebulan sekali tetapi rutin terjalin komunikasi secara tidak langsung via telepon dan lainnya. Silaturahim dengan warga dan jamaah secara lagsung dan via wa (whatsapp). Silaturahim berpengaruh terhadap pendapatan rumah tangga, yaitu semakin banyaknya link yang dimiliki maka membuka peluang untuk mendapatkan rezeki. 
Bapak Ahmad Sugeng berperan sebagai pencari nafkah dan lbu Retno Sunarsih di bagian urusan rumah tangga. Pemegang kendali keuangan adalah Ib Retno Sunarsih dengan sepengetahuan Bapak Ahmad Sugeng (unsur keterbukaan), supaya tidak menimbulkan konflik di dalamnya. Ibu Retno Sunarsih mengatur keuangan menggunakan sistem amplop dan sistem tabungan.

Rumah tangga kedua tidak mempunyai hutang, dan menempatkan zakat sebagai prioritas kedua, informan beranggapan bahwa memberi zakat tetapi keluarga masih kekurangan tidak diperbolehkan dalam Al-Qur'an, yaitu bahwa memuliakan keluarga lebih utama, akan tetapi ZISWAF tetap menjadi prioritas penting dalam pengeluaran.

Penyaluran ZISWAF melalui masjid, lembaga amal lainnya, dan melalui mustahik langsung (diutamakan keluarga terdekat). Pengeluaran zakat sesuatu dengan nasab dan ketentuan agama, sedangkan pada infak bervariasi dan dikeluarkan kapan saja. informan telah melaksankan wakaf ketika masih dinas. Sebagai takmir, informan tidak mengambil haknya sebagai amil tetapi mereka menginfakkan kepada orang lain, sebab masih ada orang lain yang lebih membutuhkan.

Rumah tangga kedua memenuhi kebutuhan sehari-hari di pasar tradisional, sedangkan untuk belanja bulanan di toko sakinah dekat dengan tempat suami mengajar di Hidayatullah. Prinsip yang dipegang dalam memenuhi kebutuhan hidup adalah berbelanja di tempat muslim, karena kalau ada untung sedikit akan disalurkan pada saudara muslim lainnya. Menggunakan tiga tabungan, yaitu dua di Bank Syariah dan satu di Bank Konvensional. Bank Konvensional bersifat darurat, karena uang pensiun diharuskan pada bank tersebut.

$$
\text { Informan telah menerapkan }
$$

wasiat, warisan, dan hibah. Informan sudah melakukan hibah dan juga pernah menerima hibah, wasiat baik secara tertulis maupun ucapan selalu dilakukan informan terutama akan bepergian jauh, dan wasiat telah dirancang oleh informan dan penerima ahli waris suami dan istri adalah Mas Farid selaku anak tunggal.

Cara rumah tangga kedua berqona'ah adalah dengan mensyukuri rezeki yang diberikan Allah seberapa pun rezeki yang diperoleh. Merasa cukup atas setiap pendapatan yang diperoleh.

Menghadapi surplus dan defisit, rumah tangga kedua menempatkan sisa dana untuk dana darurat. Tidak pernah mengalami defisit yang melebihi pendapatan, defisit yang dimaksud ialah jumlah pengeluaran lebih banyak dari pengeluaran sebelumnya, tetapi masih dalam batas wajar.

\section{Kesesuaian Sakinah Finance}

Analisis kesesuaian manajemen keuangan rumah tangga Takmir Masjid Rungkut Jaya dengan penerapan sakinah finance adalah sebagai berikut: 
Mas'amah, et al/Jurnal Ekonomi Syariah Teori dan Terapan Vol. 6 No. 6 Juni 2019: 1114-1128; MANAJEMEN KEUANGAN RUMAH TANGGA TAKMIR MASJID RUNGKUT JAYA

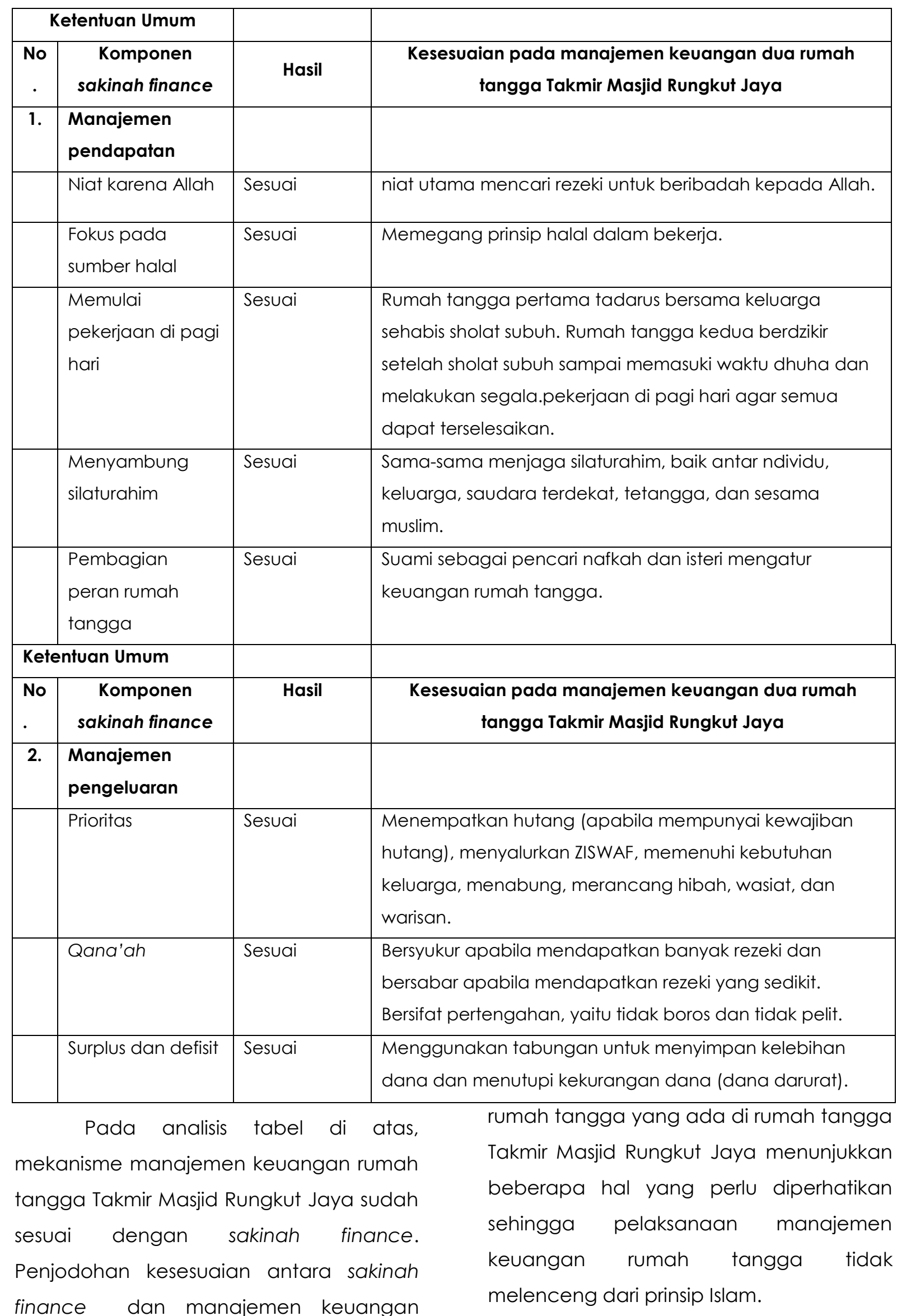




\section{SIMPULAN DAN SARAN}

\section{Simpulan}

Simpulan yang dapat diambil dari hasil analisis dan pembahasan yang telah dilakukan sebelumnya, adalah sebagai berikut:

1. Penerapan manajemen keuangan rumah tangga Takmir Masjid Rungkut Jaya sesuai dengan sakinah finance.

Penerapan sakinah finance pada manajemen pendapatan rumah tangga Takmir Masjid Rungkut Jaya, yaitu niat utama mencari rezeki untuk beribadah kepada Allah, memegang prinsip halal dan thoyib dalam mencari rezeki, memulai pekerjaan di pagi hari agar kesehatan terjaga dan semua pekerjaan cepat terselesaikan, menjaga silaturahim (keluarga, kerabat, saudara dekat, tetangga, dan saudara muslim lainnya), suami berkewajiban mencari nafkah dan istri mengatur keuangan rumah tangga dengan menerapkan unsur kepercayaan dan keterbukaan antar pasangan suami dan istri.

Penerapan sakinah finance pada manajemen pengeluaran rumah tangga Takmir Masjid Rungkut Jaya, yaitu menempatkan prioritas terpenting pada penyaluran ZISWAF, memenuhi kebutuhan pokok rumah tangga, dan tabungan. Dalam perolehan pendapatan, rumah tangga Takmir Masjid Rungkut Jaya menerapkan rasa syukur dan bersikap pertengahan dalam pengeluaran, yaitu tidak boros dan tidak pelit.

\section{Saran}

Saran yang diberikan peneliti adalah:

1. Saran untuk rumah tangga muslim, diharapkan dapat menjadi contoh dan bisa diterapkan oleh seluruh rumah tangga khususnya rumah tangga Takmir Masjid. Mengingat sebagai Negara yang mayoritas muslim yang berpedoman pada syariat Islam, maka perlu diterapkan manajemen keuangan rumah tangga yang berlandaskan prinsip Islam.

2. Saran untuk peneliti selanjutnya, diharapkan dapat meneliti topik yang sama dengan penelitian yang lebih mendalam dan dengan kriteria informan yang lebih beragam.

\section{DAFTAR PUSTAKA}

Al-Qur'an. Terjemahannya (Revisi Terbaru) Departemen Agama RI dengan transliterasi Arab-Latin. 2001. Semarang. CV. Asy Syifa.

Abdulloh, Adil Fathi. 2007. Sudah Islamikah Kelaurga Anda? Pilar-Pilar Mewjudkan Kelvarga Bahagia. Solo: Wacana llmiah Press.

Antonio, Muhammad syafi'i. 2001. Bank Syariah dari Teori ke Praktek. Jakarta: Gema Insani Press.

Antonio, Muhammad Syafi'i. 2011. Ensiklopedia Leadership dan Manajemen Muhammad SAW "The Super Leader Super Manager" Bisnis dan Kewirausahaan. Jakarta: Tazkia Publishing. 
Arnesih. 2016. Strategi Manajemen Keuangan Dalam Rumah Tangga (Berbasis Ekonomi Syariah). FKIPUNRIKA. Vol 10 Februari 2016.

Dispendukcapil Surabaya. 2016. Data Jumlah Perceraian di Surabaya. Surabaya: Dinas Kependudukan dan Pencatatan Sipil Surabaya. (http://Dispendukcapil.Surabaya.g o.id diakses pada 16 Juni 2017).

Manullang. 1981. Pengantar Ekonomi Perusahaan. Yogyakarta: Liberty.

Quthb, Sayyid. 2004. Tafsir Fi Zhilalil di bawah navangan Al-Qur'an Jilid 5. Jakarta: Gema Insani Press.

Senduk, Safir. 2000. Seri Perencanaan Kevangan Keluarga Mengelola Kevangan Keluarga. Jakarta: PT. elex Media Komputindo.

Sistem Informasi Masjid. 2017. Data jumlah masjid dan mushallah di Surabaya. Jakarta: Kementerian Agama Republik Indonesia.

(http://simas.kemenag.go.id diakses pada 28 Maret 2017).
Sugiyono. 2008. Metode Penelitian Kuantitatif Kualitatif dan R\&D. Bandung: Alfabeta.

Sulastiningsih. 2008. Cerdas Mengelola Kevangan Keluarga. Yogyakarta: Pro-U Media.

Syaparuddin. 2014. Pengelolaan Keuangan Keluarga Secara Profesional dalam Mewujudkan Kelvarga Sakinah. Watapone: AlRisalah-Jurnal Hukum Keluarga Islam. Vol 1 no. 1 Juli 2014.

Tamanni, Luqyan \& Murniati Mukhlisin. 2013. Sakinah Finance Solusi Mudah Mengatur Keuangan Kelvarga Islami. Solo: Tinta Medina. Wibawa, H. 2003. Perencanaan Keuangan Kelvarga. Jakarta: Salemba Empat.

Yin, Robert K. Tanpa Tahun. Studi Kasus Desain \& Methode. Terjemahan oleh M. Djauzi Mudzakir. 2014. Jakarta: Rajawali Pers. 